\title{
From Health Crisis to Crisis of Governance? The Dynamics of COVID-19 Policy Responses in Indonesia
}

\author{
Wawan Mas'udi \\ \{email disini\} \\ Faculty of Social and Political Science, Universitas Gadjah Mada
}

\begin{abstract}
Introduction. The COVID-19 pandemic has posed numbers of unprecedented challenges for countries around the world. Indonesia is no exception. This paper will discuss how the Indonesian government overcomes COVID-19 by identifying the policies taken by the government in responding to the pandemic crisis. This article also to explain to what extent the health crisis has triggered the crisis of governance, which mainly showed by lack of coordination among government agencies. The data to develop this article were obtained from media articles and reports from the national and international institutions and agencies. This article is organized into the following sections. The introductory section provides a brief overview of the aspects discussed related to the emergence of governance crisis as an implication of the health crisis that occurred due to the COVID-19. The second part provides an overview, in what ways the health crisis has caused several events that indicate a governance crisis, and how to overcome it. The third section describes the challenges of developing effective pandemic crisis policies, particularly to balance between health and economic interests. The fourth section explains government's response to bridging the health and economic dilemma, by explaining various social policies. The article closes with a conclusion that shows the lessons-learned of handling the pandemic crisis in Indonesia.
\end{abstract}

Keyword: Government, Institutions, Internasioan and Nasional

\section{Introduction}

\section{The Crisis of Governance: Lack of Coordination among the Government Agencies}

In a situation where the spread of the virus is getting faster and wider, the coordination between the government institutions is a fundamental point that can minimize the risk due to the impacts of pandemic, beyond the health issue. Coordination here should not only be placed in technocratic terminology which indicates cooperation between agencies in an administrative context to ensure the proper responses, but rather as a logical system that becomes the automatic mentality of the authorities' responsiveness in handling the crisis situations. In this regard, the coordination can be started from any layer of government and not 
being trapped in the hierarchy of power, and it can work either from top-down or bottom-up. In general, the handling of pandemic in Indonesia facing the following problem of coordination, which at some cases indicates the crisis of governance in managing the pandemic.

First, the absence of coordination as mindset of governance. The coordination and synergy among agencies are persistent problems in the Indonesian government system which characterized by high plurality of institutions. Regardless the character of the regime, contestation and disharmony between government actors becomes regular practices of power and implementation of the authority. Under normal circumstances, the absence of sound coordination will result inefficiency, maladministration, and failure of programs implementation. However, in a crisis situation, the absence of coordination will have severe devastating impact, because it risks the values of safety and humanity itself. Furthermore, from a technocratic perspective, the coordination is oversimplified in standard of bureaucratic procedure and administrative textbook. Even so, this is still difficult to be implemented. In a crisis context, coordination tends to be more difficult to carry out, especially when the mindset of government institutions and actors tends to pursue their own interests, rather than general public interest. The difficulties of government institutions to shift from the normal track to the abnormal one has furthermore trapped coordination as the most fundamental governance problem.

Second, the contestation and miscoordination between government actors. According to the existing regulation, the government institution supposed to coordinate other government agencies in managing crisis is the National Disaster Management Agency (BNPB). The main task of BNPB is to bridging among national government agencies, and with all levels of government, and even the community. The BNPB will be responsible to the President. Even though a top-down coordination system has been tried to be built through institutional and legal instruments during the pandemic, the contestation and miscoordination within the government, both horizontally (among government institutions at national level) and vertically (between national and local government), has been appearing during the crisis. It is often among government agencies and officials would issue the statements that are contrasted each other or not fitting in with the crisis management line of command. Also, many local governments took initiatives or policy that were outside the government's coordination line. After the government adopted numbers of government regulations, the coordination is developed, but various challenges at the operational level that require stronger synergy among government agencies would still continue.

Third, the disconnection between government policies and community initiatives. One of manifestation of the coordination problems that arise is confusion at the public level. It indicates a decline in public confidence to the dissemination government policies. This situation could lead to the delegitimization of public institutions in managing the crisis, and even could trigger the decline of government legitimacy as a whole. This situation could create a disconnect between government policies and community initiatives. In many places, the community has taken the initiative to develop communal-based emergency response. The disconnect between the government policies and community initiatives in responding the COVID-19 crisis will undoubtedly trigger not only governance crisis, but a social crisis.

\section{Results and Discussion}

Policy Responses 1: Balancing Between Health and Economy 
COVID-19 has forced the country to take drastic policies in order to overcome the health crisis, while at the same time to save the economy. In the health sector, the pandemic has caused a health crisis as a result of limited medical equipment and personnel, as well as vaccines procurement. In the economic sector, heavy impacts have been occurred. A number of countries, including Indonesia, have even officially announced the possibility of an economic recession, as a result of minus economic growth for two consecutive quarters (CNN Indonesia, 2020). In early November 2020, BPS announced that the domestic economy was minus $3.49 \%$ in the third quarter of 2020 , while in the second quarter it was minus $5.32 \%$. The head of the Fiscal Agency of the Ministry of Finance, Febrio Kacaribu, even said that the recession had occurred since the beginning of the first quarter of 2020 , considering that economic growth, which usually stands at around 5\%, but due to pandemic only reached $2.97 \%$. Recession signifies a prolonged slowdown in economic activity (Kusuma, 2020).

The downturn of economy cannot be separated from efforts to handle the health issue, especially to flatten the curve through mobility restrictions and lockdown policies. This policy to prioritize safety and the health sector has brought consequences for the cessation of economic activities, both formal and informal. Economic performance declined sharply because the consumption was declined, increasing unemployment, investment was hampered, and eventually slowing down and even decreased economic growth. In the financial sector, the volatility and financial turmoil were felt immediately since the outbreak, along with the decline in investor confidence due to the crisis. The financial sector was also affected through the decline in the performance of the real sector (Kacaribu, 2020).

The decline in economic growth due to COVID-19 has resulted in an increase in the number of layoffs, unemployment, and poverty. The Central Statistics Agency (BPS) stated that as of March 2020 the unemployment rate was 26.42 million people or $9.78 \%$. This figure increased from the previous year which was $9.41 \%$ or 25.14 million people. The poverty rate has also increased, especially among the informal sector. In addition, the poverty rate in rural areas has also increased. In March 2020, the Poverty Depth Index in urban areas was 1.13, while in rural areas was 2.21. Meanwhile the Poverty Severity Index in urban areas is 0.25, and in the rural areas is 0.55 (BPS, 2020). Regarding the unemployment rate, data from the Ministry of Manpower shows, as of July 31, 2020, the number of workers affected by termination of employment (PHK) or being laid off was 3.5 million people. Meanwhile, based on data from the Social Security Administering Body (BPJS), the people affected (by name and by address) by the pandemic reached 2.2 million people, and most of them are laid off or terminated their informal economy (Karunia, 2020).

In the midst of the possibility of economic crisis driven by the health crisis, many countries have taken policies to prevent it. The economic policies taken are very diverse, but in general they include: 1) social assistance; 2) business incentives; 3) fiscal facilities; 4) budget reallocation; and 5) economic recovery policy. The IMF noted that almost all countries have reallocated and refocused policies to ensure that the economic impact on citizens (especially the poor) does not get worse, as well as a policy package to carry out post-pandemic recovery. Indonesia is not an exception, where the Government takes various forms of policies to provide various direct assistance to affected communities and a number of economic recovery policy packages. It includes the following aspects of policy:

\section{a) Policy 1: Macro Policy and Budget Re-allocation}


The direction of economic policy for managing COVID-19 and its impact is reflected in a number of government macro policies and in the budget re-allocation policy. This section describes a number of macro policies, especially in the form of government regulations and other directives or briefings delivered primarily by the President and ministers. By explaining the basic policies, it can be traced the government's priorities in handling COVID-19, and also the resources allocated for fighting the pandemic. Furthermore, the policy also includes the economic recovery plan prepared by the government, both during the crisis and recovery. Given the nationwide scope of the pandemic, the role of local governments (provincial and district/city) in economic recovery is also very important.

COVID-19 is a challenge for the government due to its extraordinariness and unprecedented. The Minister of Finance, Sri Mulyani, said the unprecedented condition of COVID-19 has forced the government to change the direction of policy (CNN, 2020). At the beginning of the pandemic, at the end of March, President Joko Widodo emphasized that the COVID-19 pandemic was not only related to health and safety, but also the economic impacts. To save the economy in the midst of a pandemic, President Jokowi announced nine policies (Ihsanuddin, 2020), namely:

1. Giving instruction to ministers, governors and mayors to cut budget plans and nonessential expenditures.

2. Asking the central government and local governments to allocate budgets to accelerate the alleviation of the pandemic impact, both in health and economy.

3. Asking the central government and local governments to guarantee the availability of basic commodities, followed by ensuring that the purchasing capacity of the people, especially the lower classes is maintained.

4. Requesting the Cash for Work Intensive program to be reproduced and multiplied, with a note that it must be followed by compliance with the corona virus prevention protocol.

5. The government provides an additional 50,000 rupiah to the holders of food cards for six months. Thus, the food card holders will receive 200,000 rupiah per family per month.

6. Accelerating the implementation of pre-employment cards to anticipate workers who are laid off, workers who lose their income, and small-entrepreneurs.

7. The government would postpone the additional tax (PPh) Article 21, which used to be paid by taxpayers (WP) employees in the processing industry.

8. The Financial Services Authority (OJK) provides credit relaxation under 10 billion rupiah for the Micro, Small and Medium Enterprises. The relaxation is in the form of lower interest rates and a year's postponement of installments, both from bank and the non-bank financial industry.

9. People with low incomes who get subsidy of Housing Ownership Credit (KPR) will get a stimulus. The government provides interest subsidies for up to 10 years of installments. If the interest is above $5 \%$, the difference in interest is paid by the government. In addition, there is assistance in providing down payment subsidies for subsidized housing loans.

Following-up the instruction, two regulations aimed to respond the crisis and in order to save the economy was adopted, namely: 1) Government Regulation in Lieu of Law No. 1 of 2020 which is stipulated to be Law No. 2 of 2020 on State Financial Policy and Financial System Stability for Handling the Covid-19 Pandemic; and 2) Presidential Regulation No. 54 of 2020 concerning Changes in Posture and Details of the 2020 State Revenue and Expenditure.

In the midst of the threat of recession, the government issued other policy, namely Government Regulation Number 23 of 2020 on National Economic Recovery program in order to handle the significant impact of the COVID-19 pandemic on the country's economy. 
PEN aims to protect, maintain, and strengthen economic capacity (article 2). The principles of PEN program implementation are including: the principle of justice, as much as possible for the prosperity of the people, supporting business actors, applying prudential policy principles, as well as good, transparent, accelerative, fair and accountable governance, and sharing of costs and risks among stakeholders according to their respective duties and authorities. In its implementation, the government adopts five strategies: equity participation, placement of funds, government investment, guarantees, and policies through state spending. The source of funds for the implementation of PEN comes from the state budget in accordance with the provisions of the legislation.

Some ministers are responsible for formulating and establishing policies and strategies for implementing PEN, namely; Coordinating Minister for Economic Affairs, Coordinating Minister for Maritime Affairs and Investment, Ministers, Governor of Bank Indonesia, Chairman of the OJK Board of Commissioners, and Chairman of the Board of Commissioners of the Deposit Insurance Corporation. The main responsibility is to formulate policy priorities for business sectors or sectors affected by the COVID-19 pandemic, which must be approved by the President (Chrysna, 2020). The PEN program is divided into six clusters: health, social protection, support for small and medium enterprises, business incentives, corporate financing, and specific program for tourism sector, ICT infrastructure, and labor-intensive programs (Putra, 2020).

The Ministry of Finance has allocated budget for handling Indonesia's COVID-19 at about 695.2 trillion rupiah. Of this amount, as of October 6 , the allocation for the health cluster 87.93 trillion, social protection cluster 239.53 trillion, MSME cluster 128 trillion, for business incentives 120.61 trillion, corporate financing 48.85 trillion, and sectoral ministries/agencies $\&$ local government 70.10 trillion (Yoshio, 2020). By mid-November 2020, 383.01 trillion or $55.1 \%$ of the PEN budget allocation had been realized, as stated by the Minister of Finance, Sri Mulyani in a Working Meeting with Commission XI of the House of Representatives (DPR), November 12, 2020. In the health cluster there was an adjustment ceiling to 97.26 trillion rupiah. This ceiling includes vaccines program of 29.23 trillion rupiah. With the adjustment of the ceiling, the realization of PEN in the health cluster is 34.07 trillion or $35 \%$. The benefits of this health cluster program are for health workers, spending on COVID-19 handling, the task force for handling COVID-19, compensation for the death of health workers, assistance for National Health Insurance (JKN) contributions, and tax incentives for health-related business and services.

The progress of the realization of the social protection reached $77.3 \%$ or 181 trillion, out of 234.33 trillion rupiah. The recipients of this social protection program include the Family Hope Program receiver which reaches 10 million families, 19.4 million food cards beneficiaries, 9 million additional social assistance, and almost 2 million basic necessities social assistance in Greater Jakarta, 9.2 million in non-Jabodetabek area, and Village Fund. The social protection budgets are also to support Distance Learning and improve access to the labor market or self-employment. The subsidy for distance learning is universal for students, teachers, and lecturers.

\section{b) Policy Response 2: Social Assistance Policies}

In order to prevent people from severe vulnerability, the government also adopted policies on social assistance. As a result of the restriction of socio-economic activities, millions of individuals and households faced difficulties to meet basic living needs. This section describes the various forms of social assistance and the resources needed for these programs. The main 
beneficiaries of the social assistance are also discussed, considering that different types of programs indicate different beneficiaries. Furthermore, the implementation of social assistance program faces many challenges, both in terms of the institutions that manage it and database for distribution of aid. Social assistance programs, both on individuals and families basis, can be described as follows (Pratama, 2020; Public Relations of Setkab 2020):

1. Family Hope Program (PKH)

The Family Hope Program is designated for 10 million poor families. The benefit of this program includes: pregnant women is 3 million rupiah/year, early age is 3 million rupiah/year, elementary school children (SD) 900 thousand rupiah/year, junior high school (SMP) children 1.5 million, high school children (SMA) 2 million rupiah/year, severe disability 2.4 million rupiah/year, and elderly 70 years and over 2.4 million rupiah/year. PKH Component Assistance is given for a maximum of 4 peoples in a family. The distribution is carried out every month for one year, starting April 2020. Total budget allocated for this program is 37.4 trillion (Ministry of Finance, 2020)

2. Food Card/Non-Cash Food Assistance, and Jabodetabek Social Assistance

The recipients of the Food Card are 20 million heads of families consisted 15.2 million the existing recipients and 4.8 million new recipients. The amount of benefit is equal to 200.00 rupiah/month. The basic food cards are given from April to December 2020 for consumption of basic needs such as rice, eggs, tempeh, tofu, fish and vegetables. The budget allocation is 43.6 trillion rupiah (Ministry of Finance, 2020). The Jabodetabek food assistance, worth 600,000 per month, is distributed through the Ministry of Social Affairs for 1.9 million Jabodetabek residents. Food assistance is distributed every 2 weeks with each distribution worth 300,000 rupiah (Ministry of Social Affairs, 2020)

3. Direct Village Fund Cash Assistance

This program is designed to assist poor family living in the village area. The amount of the assistance is 600,000 rupiah/month for three months (April-June). The budget was allocated from a maximum of $35 \%$ of village funds or if exceed of $35 \%$ required approval from the district/city government. Recipients of the Village Fund BLT are poor families in the village who are not the recipients of either PKH, Basic Food Cards, and PreEmployment Cards. The data of the recipients provided by the village head and was integrated in the Integrated Social Welfare Data (DTKS) developed by the Ministry of Social Affairs. The village head is responsible for the use of village funds. The use of village funds in stages I and II is prioritized for the cash transfer assistance. In a village government fails to meet the target, the sanction is a termination of distribution of village funds in phase III of the current fiscal year. In addition, the sanction is also in the form of cutting village funds by $50 \%$ in the following fiscal year (Kemenkeu, 2020).

4. Electricity Discount Program

For this program, the allocation of budget is 3.5 trillion in 2020 state budget spending. This electricity discount is given from April to June 2020. For the households with 450 VA are bill-free, while 900 VA household customers are subsidized with a 50\% discount (Kemenkeu, 2020).

5. Salary Subsidy Program

Salary and wages subsidy for workers/labor is worth of 600,000 rupiah/month for four months, and is disbursed in two stages. The target recipient is 15.7 million workers/labor, with the following requirements (Ministry of Finance, 2020):

a. Indonesian citizen.

b. Registered as an active participant in the BPJS Employment Social Security program.

c. Workers or labors receiving routine salary/wages 
d. Having membership of BPJS until June 2020

e. Active participants of the Employment Social Security program

f. Have an active bank account.

6. Pre-Employment Card Program

The Pre-Employment Card is intended for 5.6 million participants. The criteria for participants are job seekers, informal/formal workers and micro and small business owners affected by COVID-19. The amount of the benefit consists of a training fee of 1 million rupiah, a post-training incentive of 600,000 rupiah/month for four months, and a job survey incentive of 50,000. The total budget for this program is 20 trillion rupiah (Ministry of Finance, 2020). A number of controversies accompany this policy, including the existence of online training on Pre-Employment Cards that do not meet the required competencies, the appointment of Ruang Guru, ex-Presidential staff companies as training partners, the prices of some online trainings are too expensive, the Pre-Employment Card incentive is late, and the amount of the budget reaches 20 trillion rupiah (Idris, 2020). The Minister of Social Affairs, Juliari P Batubara, stated, the largest distribution of the PEN program comes from social protection programs.

\section{Conclusion}

The case of COVID-19 in Indonesia reveals two important issues, first, the health crisis in many countries, including Indonesia, has triggered some aspect of governance crisis. Second, the crisis went beyond health crisis, and has transformed into an economic and social problem. In managing this issue, a further question that arises is what 'normality' will be with COVID19 or after COVID-19. The discourse of "New Adaptation" or "New Normal" is now becoming public discussion. The challenge in the practice of "New Adaptation" is how to accelerate vaccination as an answer to prepare for the new normal, to develop more effective policy, and to strengthen community resilience.

\section{References}

[1] Afrianto, Dedy. 2021. Pergerakan Laju Vaksinasi Mulai Berubah. Kompas, 26 Oktober. https://www.kompas.id/baca/riset/2021/10/26/pergerakan-laju-vaksinasimulai-berubah

[2] Aldila, Nindya. 2020. Dua Tantangan Terbesar Distribusi Vaksin COVID-19 di Indonesia. Bisnis, $14 \quad$ Desember. https://kabar24.bisnis.com/read/20201214/15/1330760/dua-tantangan-terbesardistribusi-vaksin-covid-19-di-indonesia

[3] Amalia, Yunita. 2021. Kendala Vaksinasi di DKI karena Ketimpangan Jumlah Vaksinator dan Penerima Vaksin. Merdeka, 7 April 2021. https://www.merdeka.com/jakarta/kendala-vaksinasi-di-dki-karena-ketimpanganjumlah-vaksinator-dan-penerima-vaksin.html

[4] Antara. 2021. Berapa Anggaran Impor Vaksin COVID-19 Tahun Ini? Tempo, 28 Agustus. https://bisnis.tempo.co/read/1499683/berapa-anggaran-impor-vaksin-covid19-tahun-ini/full\&view=ok 
[5] Astika. 2021. Daftar 10 Jenis Vaksin COVID-19 di Indonesia, Mana yang Terbaik? Detik, 29 Oktober. https://health.detik.com/berita-detikhealth/d-5788677/daftar-10jenis-vaksin-covid-19-di-indonesia-mana-yang-terbaik

[6] Astungkoro, Ronggo. 2021. Jokowi Akui Sulit Mainkan 'Gas-Rem' Pada Penanganan COVID-19. Republika, 28 Agustus. https://www.republika.co.id/berita/qyjjmq354/jokowi-akui-sulit-mainkan-gasrem-padapenanganan-covid

[7] Aulia, Adam. 2020. 'Kikuknya' Menkes Terawan Menghadapi COVID-19. Tirto, 11 Maret. https://tirto.id/kikuknya-menkes-terawan-menghadapi-covid-19-eD3a

[8] Bona, Maria Fatima. 2021. Kemkes Gandeng Polri dan TNI untuk Tracing dan Vaksinasi COVID-19. Detik, 11 Februari. https://www.beritasatu.com/kesehatan/731749/kemkes-gandeng-polri-dan-tni-untuktracing-dan-vaksinasi-covid19

[9] Kumparan. 2021. RI Impor Vaksin Corona Rp 2,14 Triliun per Juli 2021, Terbanyak dari China. Kumparan, 18 Agustus. https://kumparan.com/kumparanbisnis/ri-imporvaksin-corona-rp-2-14-triliun-per-juli-2021-terbanyak-dari-china-1wM52QEk8Sm/full

[10] Nugraheny, Dian Erika. 2021. Dimulainya Vaksinasi COVID-19 di Indonesia. Kompas, $14 \quad$ Januari. https://nasional.kompas.com/read/2021/01/14/06572221/dimulainya-vaksinasi-covid19-di-indonesia

[11] Putri, Aditya Widya. 2021. Konten Antivaksin Bisa Hambat Vaksinasi COVID-19 di Indonesia. Tirto, 3 Februari. https://tirto.id/konten-antivaksin-bisa-hambat-vaksinasicovid-19-di-indonesia-f9C3

[12] Saputri, Dessy Suciati. 2021. Kemenkes: Laju Vaksinasi COVID-19 Terkendala Distribusi. Republika, 21 Juli. https://republika.co.id/berita/qw14ch384/kemenkes-lajuvaksinasi-covid19-terkendala-distribusi

[13] Sari, Amalia Purnama. 2021. Capaian Vaksinasi COVID-19 Dosis Pertama Tembus 56,00\%. Kompas, 28 Oktober. https://www.msn.com/id-id/berita/nasional/update-28oktober-capaian-vaksinasi-covid-19-dosis-pertama-tembus-56-00-persen/ar-AAQ2UaG

[14] VoA Indonesia. 2020. Jokowi Minta Hindari "Polemik" Terkait Penanganan COVID19. VoA Indonesia, 4 Oktober. https://www.voaindonesia.com/a/jokowi-minta-hindaripolemik-terkait-penanganan-covid-19/5608125.html

[15] Peraturan Presiden Republik Indonesia Nomor 82 Tahun 2020 tentang Komite Penanganan Corona Virus Disease-19 dan Pemulihan Ekonomi

[16] BPS. 2020. Profil Kemiskinan di Indonesia, Maret 2020. No.56/07/Th. XXIII, 15 Juli 2020.

[17] Chryshna, Mahatma. 2020. PP tentang Program Pemulihan Ekonomi Nasional (PEN) Tahun 2020. Kompas, $22 \quad$ September. https://kompaspedia.kompas.id/baca/data/dokumen/pp-tentang-program-pemulihanekonomi-nasional-pen-tahun-2020

[18] CNN Indonesia. 2020 Menkeu Ungkap Tantangan Kebijakan Ekonomi di Tengah COVID-19. CNNIndonesia, 4 Juli. https://www.cnnindonesia.com/ekonomi/20200704180858-78-520858/menkeuungkap-tantangan-kebijakan-ekonomi-di-tengah-COVID-19

[19] CNN Indonesia. 2020. RI Resmi Terjerat Resesi. CNN Indonesia, 6 November. https://www.cnnindonesia.com/ekonomi/20201106061542-532-566546/ri-resmiterjerat-resesi-ekonomi 
[20] Gitiyarko, Vincentius. 2020. Kebijakan Perlindungan dan Pemulihan UMKM di Tengah Pandemi COVID-19. Kompas, 31 Agustus. https://kompaspedia.kompas.id/baca/paparan-topik/kebijakan-perlindungan-danpemulihan-umkm-di-tengah-pandemi-covid-19

[21] Humas Setkab-a. 2020. Realisasi Anggaran Pemulihan Ekonomi Nasional Capai Rp 383,01 Triliun. Setkab, 13 November. https://setkab.go.id/realisasi-anggaranpemulihan-ekonomi-nasional-capai-rp38301-triliun/

[22] Humas Setkab-b, Progres Realisasi Program Pemulihan Ekonomi Nasional (PEN), Klaster Perlindungan Sosial, 26 September 2020, di Istana Kepresidenan Bogor, Provinsi Jawa Barat. Setkab, 26 September. https://setkab.go.id/progres-realisasiprogram-pemulihan-ekonomi-nasional-pen-klaster-perlindungan-sosial-26-september2020-di-istana-kepresidenan-bogor-provinsi-jawa-barat

[23] Idris, M. 2020. Kontroversi Kartu Prakerja, dari Temuan KPK hingga Keterlibatan $\begin{array}{llll}\text { Perusahaan } \quad \text { Stafsus. } & \text { Kompas, Juni. }\end{array}$ https://money.kompas.com/read/2020/06/23/140205226/kontroversi-kartu-prakerjadari-temuan-kpk-hingga-keterlibatan-perusahaan?page=all (diakses 26 Juli 2020). 